\title{
PRE-SCHOOL AGE VISUALLY IMPAIRED CHILDREN'S MOTIVES FOR LEARNING
}

\author{
Vytautas Gudonis \\ Siauliai university, Lithuania
}

\begin{abstract}
The article presents longitudinal data of the survey of 212 Šiauliai Petras Avižonis Visual Centre's 6-7-year-old pre-school children's motives to attend school. A brief theoretical analysis of significance of motives for learning in child's development is displayed. Analysing research results, a positive experience on development of positive motives for school attendance in pre-school age children attending Šiauliai Petras Avižonis Visual Centre is rendered in a generalising way.
\end{abstract}

Keywords: pre-school age, visually impaired children, motives to attend school.

\section{Introduction}

Unwillingness of comprehensive education school pupils to learn and the coping with it are the most complex problem in contemporary education; much attention is focused to solve it. Learning becomes a more complex activity of a pupil; it requires various abilities and conditions development of a full-fledged personality. The problem of motivation for learning is made relevant by children not attending school. Also, pupils' unwillingness to attend school remains relevant too (Barkauskaitè, Motiejūnienè, 2004; Barkauskatè, 2008 etc.). Researchers are interested in motivation for learning not only of pupils, but also of students attending institutions of higher education (Leonavičius, 1996, Lipinskaitè, 2002, Radzevičiūtè, 2003, Paliukaitè, 2005, 2007, Salienè, 2011 etc.). Kaffemanienè and Ivoškutè investigated interrelations between anxiety and motives for learning (2005). There are not quite many works familiar to us dedicated to investigation of motivation of children with special educational needs and adults with disabilities. Only several research works carried out earlier on the issue discussed can be mentioned: Солнцева (1965) investigated importance of motives in education of pre-school age children's activeness; Стернина (1977) examined education of visually impaired adolescents' motives for societal activities; Gudonis (1979, 1979a, 1984) carried out research on visually impaired working youth's and adults' motivation for learning, blind and visually impaired adult people's motives for rehabilitation, visually impaired people's motives for societal activities (Гудонис, 1989), motivation for learning of pupils with speech disorders (Gudonis, Rumšienè, 2012). Therefore, the researchers are interested in children's and youth's motivation for learning, starting with primary level pupils and finalising with students attending higher education institutions. All this can be treated as a relevant pedagogical problem. However, we hold the opinion that the beginning of the motivation for learning 
should be sought for in a pre-school age. We could not find any research on preschool age visually impaired children's motives for school attendance. This encouraged us to carry out a research presented below.

The aim of the research is to survey pre-school age visually impaired children's motivation for learning.

Research participants: 212 pupils of pre-school groups at Šiauliai Petras Avižonis Visual Centre took part in the research. The average age of the surveyed was 6.5 , the sharpness of vision was V $0.3-1$.

Research methods: 1) theoretical: analysis of scientific literature; 2) empirical: interview.

\section{Importance of Motivation for Learning}

Pupils' unwillingness to systemically carry out teaching tasks, absence at school, missing of lessons and the outcome of it, i.e. failure in learning, are the obstacles for implementation of the aims of the education system. Research studies on causes of unwillingness to learn conducted by Dereškevičius, Rimkevičienè, Targamadzè (2000), Beresnevičienė (1995), Rupšienè (1999, 2000, 2004), Spurga (2000), Šiaučiukienè, Visockienè, Talijūnienè (2006) and others show that pupils most often "drop out" from school, do not want to attend school and learn due to weakened motivation for learning. Thus, the lack of motivated and purpose-directed activities is one of the major reasons for unwillingness to learn. Barkauskaite and Motiejūniené (2004) state that motivation for learning depends on a broad spectrum of factors: both "inner" interest and fear to be punished. Motivation for learning defines the relation between learning and grounding (Butkienè, 1995). Learning is possible only when human's actions are controlled by a conscious purpose to obtain certain knowledge, skills, abilities (Juška, 1997). Therefore, as the scientist holds it, motivation for learning is what really encourages a child to learn and ensures one's successful learning. Butkienè and Kepalaitè (1996) support a similar opinion: they state that motivation for learning helps a child to get better oriented towards the purpose.

According to the relation between a motive and individual's activity level, internal and external motives are distinguished. As Rupšiene (2000) puts it, the learning is determined by various motives of different value: some motives stimulate learning more than others. Therefore, the author tends to divide motives into two major groups, referring to criteria of their significance, meaningfulness:

1) internal (primary) motives for learning are more valuable because they are related to secondary viewing of the meaning of learning;

2) external (secondary) motives: they can be significant, however, they are related to external environment but not learning needs.

According to Butkienè and Kepalaite (1996), internal motives arise from the subject himself/herself and are less changing than short-term external 
motives. External motives are more often short-term than internal impulses (Lehmann, 2009). It is considered that an interest is one of the strongest motives (Vygotskis, 1999). An interest is a natural engine of behaviour, and an attitude acts as a regular emotional response motivated by beliefs (Ruggiero, 1998). According to Edwards (1994), an attitude may appear as an intent, wish to act favourably or unfavourably concerning certain objects. According to levels, motives for learning are divided into:

1) broad social motives (duty, responsibility, understanding of social significance of learning);

2) narrow social motives (a striving to occupy a certain position in society in the future, to be acknowledged, to receive an appropriate salary);

3) training cognitive motives (orientation to the ways of obtaining knowledge, understanding of particular training programmes);

4) social collaboration motives (establishment of own role and position in a group, orientation towards various ways of communication with other people);

5) self-education motives (orientation towards the acquisition of additional knowledge);

6) broad cognitive motives (interest in environment, satisfaction with learning activities etc.) (Подласый, 1999).

The same author suggests dividing motives for learning on the ground of the content and purposefulness into: social, cognitive, professional-value, aesthetical, communicative, status-positional, traditional-historical, utilitarianpractical.

\section{Results of the Longitudinal Research}

Pre-school age children's visual disorders deprive their mental health. Visually impaired children very early understand their exceptionality: they wear glasses, quite often with one eye covered (in a case of amblyopia), their vision is poorer than other children's. This negative exceptionality diminishes children's self-value, makes their adjustment in a new group of peers a new environment more difficult. Due to lower self-value, more difficult adjustment, diffidence appears; it smothers child's activeness, initiative. These children have more emotional and behavioural difficulties. Disorders of moods, attention and activity are more common. Problems of communication with contemporaries and adults occur more often. Avoiding social contacts, children do not obtain or obtain poor social skills. Poor mental health of visually impaired children prevents them achieving the required level of school maturity, also makes the processes of their socialisation slower. Traditionally, in pre-school education institutions school maturity and motivation for learning are surveyed when six to seven-year-old children graduate from the pre-school facility. Having estimated pupil's negative motivation for learning or low level of maturity, it is impossible 
to correct it because a child leaves the institution. Aiming to improve such a situation, in 2005 we started studying Šiauliai Petras Avižonis Visual Centre's pre-school age children's motivation for learning and school maturity twice a year (the first survey was carried out in September, the other in May). On the ground of the first research results, a psychologist of the institution prepared recommendations for each child's parents and group teacher.

On the ground of obtained results based on interviews with children, we divided motivation for attending school into three levels (see Table 1). To estimate a high level of motivation, we attributed socially significant motives. For example, a girl of 6.7 years of age: <...I wan to go to school to learn a lot... $>$. We attributed positive though socially insignificant motives for school attendance to the average level. For instance, a girl E., age 6.10 years of age $<\ldots I$ want to go to school because I won't need to sleep at noon... >. The negative level was attributed with the cases when a child categorically expresses his/her unwillingness to go to school. For example, a boy U., age 6.7 years of age $<\ldots I$ don't want $t$ go to school because I'm already fed up with learning... .

Table 1. Indices of pre-school age children's motives to attend school $(\mathrm{N}=\mathbf{2 1 2})$

\begin{tabular}{|c|c|c|c|c|c|c|c|c|c|c|c|c|}
\hline \multirow{3}{*}{ Indices } & \multicolumn{4}{|c|}{$2013 / 2014$} & \multicolumn{4}{|c|}{$2012 / 2013$} & \multicolumn{4}{|c|}{$2011 / 2012$} \\
\hline & \multicolumn{2}{|c|}{ September } & \multicolumn{2}{|c|}{ May } & \multicolumn{2}{|c|}{ September } & \multicolumn{2}{|c|}{ May } & \multicolumn{2}{|c|}{ September } & \multicolumn{2}{|c|}{ May } \\
\hline & amount & $\%$ & amount & $\%$ & amount & $\%$ & amount & $\%$ & amount & $\%$ & amount & $\%$ \\
\hline \begin{tabular}{|l|} 
Positive, \\
socially \\
signifi- \\
cant \\
\end{tabular} & 10 & 45.4 & 12 & 54.5 & 5 & 17.8 & 10 & 35.7 & 10 & 52.6 & 14 & 73.7 \\
\hline \begin{tabular}{|l|} 
Positive, \\
socially \\
insigni- \\
ficant
\end{tabular} & 8 & 36.4 & 8 & 36.4 & 12 & 48.8 & 15 & 53.6 & 6 & 31.6 & 4 & 21 \\
\hline Negative & 4 & 18.2 & 2 & 9 & 11 & 39.3 & 3 & 10.7 & 3 & 15.8 & 1 & 5.3 \\
\hline
\end{tabular}

\begin{tabular}{|l|c|c|c|c|c|c|c|c|c|c|c|c|}
\hline \multirow{2}{*}{ Indices } & \multicolumn{3}{|c|}{$2010 / 2011$} & \multicolumn{3}{c|}{$2009 / 2010$} & \multicolumn{3}{c|}{$2008 / 2009$} \\
\cline { 2 - 13 } & September & \multicolumn{2}{c|}{ May } & September & \multicolumn{2}{c|}{ May } & \multicolumn{2}{c|}{ September } & \multicolumn{2}{c|}{ May } \\
\cline { 2 - 13 } & amount & $\%$ & amount & $\%$ & amount & $\%$ & amount & $\%$ & amount & $\%$ & amount & $\%$ \\
\hline $\begin{array}{l}\text { Positive, } \\
\text { socially } \\
\text { significant }\end{array}$ & 15 & 53.6 & 20 & 71.4 & 7 & 31.8 & 9 & 41 & 8 & 26.6 & 16 & 53.3 \\
\hline $\begin{array}{l}\text { Positive, } \\
\text { socially } \\
\text { insigni- } \\
\text { ficant }\end{array}$ & 6 & 21.4 & 6 & 21.4 & 10 & 45.4 & 11 & 50 & 15 & 50 & 10 & 33.3 \\
\hline Negative & 7 & 25 & 2 & 7.1 & 5 & 22.7 & 2 & 9 & 7 & 23.3 & 4 & 13.3 \\
\hline
\end{tabular}


SOCIETY. INTEGRATION. EDUCATION. Volume II

\begin{tabular}{|l|c|c|c|c|c|c|c|c|c|c|c|c|}
\hline \multirow{2}{*}{\begin{tabular}{l} 
Indices \\
\cline { 2 - 12 }
\end{tabular}} & \multicolumn{3}{|c|}{$2007 / 2008$} & \multicolumn{3}{c|}{$2006 / 2007$} & \multicolumn{3}{c|}{$2005 / 2006$} \\
\cline { 2 - 12 } \\
\cline { 2 - 12 } & September & \multicolumn{2}{c|}{ May } & \multicolumn{2}{c|}{ September } & \multicolumn{2}{c|}{ May } & \multicolumn{2}{c|}{ September } & \multicolumn{2}{c|}{ May } \\
\hline $\begin{array}{l}\text { Positive, } \\
\text { socially } \\
\text { significant }\end{array}$ & 8 & 33.3 & 4 & 16.7 & 11 & 36.6 & 11 & 36.6 & 3 & 1.7 & 3 & 1.7 \\
\hline $\begin{array}{l}\text { Positive, } \\
\text { socially } \\
\text { insigni- } \\
\text { ficant }\end{array}$ & 10 & 41.7 & 17 & 70.8 & 8 & 26.7 & 12 & 40 & 10 & 55.5 & 9 & 50 \\
\hline Negative & 6 & 25 & 3 & 12.5 & 11 & 36.6 & 7 & 23.3 & 5 & 27.8 & 5 & 27.8 \\
\hline
\end{tabular}

\begin{tabular}{|l|c|c|c|c|c|c|}
\hline \multirow{2}{*}{ Indices } & \multicolumn{5}{|c|}{$2004 / 2005$} & \multicolumn{2}{c|}{ May } \\
\cline { 2 - 7 } & \multicolumn{2}{|c|}{ September } & \multicolumn{2}{c|}{ May } & \multicolumn{2}{c|}{} \\
\cline { 2 - 7 } & amount & $\%$ & amount & $\%$ & amount & $\%$ \\
\hline $\begin{array}{l}\text { Positive, socially } \\
\text { significant }\end{array}$ & 7 & 26.9 & 8 & 25 & 5 & 17.2 \\
\hline $\begin{array}{l}\text { Positive, socially } \\
\text { insignificant }\end{array}$ & 11 & 42.3 & 9 & 28.1 & 11 & 37.9 \\
\hline Negative & 8 & 30.8 & 15 & 46.9 & 13 & 44.8 \\
\hline
\end{tabular}

The psychologist recommends educators (pedagogues and parents) to relate attendance of school with child's future professional aspirations when educating children who have negative motivation for attending school. Also, the psychologist recommended allocate more time for acquaintance of pre-school age children with diversity of professions throughout school year. After this work, motivation of majority of pupils changed towards positive motivation. For instance, a girl G., age 6.6 years of age, in the interview in September stated: $<. . . I$ don't want to go to school because it will be difficult there, I will need to read all the time, then write, and after a break continue working. When I grow up I would like to be a doctor of animals.... > . During analogous survey in May: $<.$. I wish to go to school because I want to be a doctor of animals. I will go to school; afterwards I will attend a university. I will be a doctor; if an animal gets sick I'll take a syringe and inject some medicine to make it recover. I will earn money. And when I give birth to children, my mother will become a grandmother and my father will become a grandfather...>. A boy D., age 6.1 years, in the survey in September: $<$... I won't go to school because it'll be hard to learn...>. The psychologist asks: $<$ What will you do if not attend school? $>$. The child replies: <I'll not go to school, I'll retire; when I grow up I'll be a policeman, I'll be catching thieves... >. In the survey in May: <...I'll go to school because I must learn writing. When I stop a car I'll need to write a fine receipt. When I finish school I'll attend the police academy and learn shooting...>. An assumption can be drawn that already in pre-school age narrow 
social motives, i.e. a striving to obtain a profession, to occupy a certain position in society in the future, to receive an appropriate salary, start developing (Подласый, 1999).

However, even though making efforts to purposefully develop positive motives to attend school, in the period 2007-2014 we did not succeed in correction of negative motives for school attendance in a small part on the average of $11.9 \%$ of children. It is likely that the close environment has made a greater impact on these children rather than pedagogues' explanation on the benefits and necessity of learning, diversity of professions and professions children dream of. For instance, in the survey in May: a girl V., age 7.4 years of age... I don't want to go to school. My sister attends the $4^{\text {th }}$ form and it's difficult for her to learn; therefore it will be hard for me too... >. The same reason for not wishing to attend school was indicated by this girl in the survey in September, too.

This data proves the opinions held by Teresevičienè, Gedvilienè, Zuzavičiūtè (2006) as well as Šiaučiukienè, Visockienė, Talijūnienè (2005) stating that when choosing methods of teaching, a pedagogue not only must direct attention to what would help children obtain knowledge and consolidate it to maximally develop practical and intellectual skills, but also develop motivation for learning. Pedagogues state that part of parents, wishing to motivate their children for school, turn to the class-teacher for consultations; however, part of the parents leave this issue as it is.

Results of the longitudinal research carried out throughout 2003-2014 show that in September Šiauliai Petras Avižonis Visual Centre receives preschool groups of children among whom from 18.2 to 39.3 per cent demonstrate a low level of motivation for school. Partially, this negative tendency can be explained by the reason that parents, who do not understand the significance of communication with their child, devote increasingly less time to communication with him or her. Another circumstance complicating development of child's positive motivation for learning deals with the issue of part of children living in incomplete families. Some mothers are divorced, some husbands are working abroad. Some children who took part in the survey live with grandparents because their parents live and work abroad. Due to mentioned circumstances, a pre-school age child feels deficit of communication with both adults and peers this makes a negative impact on child's motivation for school attendance and one's socialisation. Therefore, it is highly important for children to attend an institution of pre-school education, also to have a psychologist working in that institution. Presently, a psychologist is working in one Šiauliai pre-school education institution - Šiauliai Petras Avižonis Visual Centre only. 


\section{Conclusions}

1. Having analysed scientific literature, it can be stated that motives are both complex and dynamic phenomena and serve as external or internal factors that stimulate individual's activity and determine the direction of his or her activities, whereas motivation is a system of constant motives that initiate, direct and support purposeful actions.

2. It was determined that the most common factors that enhance motivation for learning are as following: purposeful organisation of the learning process based on pupils' needs, identification of possibilities for setting aims of activities, adequate assessment of pupils' achievements, improvement of the relationship between pupils, parents and teachers, enhancement of internal and external motivation for learning through reinforcement of cognition, self-expression, achievement of future goals, communication, prestige as well as utilization of different external stimuli.

3. Results of investigation of visually impaired pre-school children's motives to attend school proved significance of pre-school education institutions in preparing visually impaired children for school.

4. It has been found that when surveying children of pre-school groups on a bi-annual basis year, i.e. in September and May, as well as preparing and using recommendations for pedagogues and parents drawn by a psychologist, pupils' motives to attend school become more positive.

\section{References}

Barkauskaitė M., Motiejūnienė E. (2004). Mokymosi motyvacijos problema ir jos sprendimo galimybès. Pedagogika, 70, 38-44.

Barkauskaitè ir kt. (2008). Nesékmingo mokymosi mastai ir priežastys: tiriamasis darbas, ataskaita. Vilnius.

Beresnevičienè, D. (1995). Suaugusiųjų mokyklų moksleivių mokymosi motyvacijos veiksniai. Pedagogika, 31, 171-181.

Butkienė, G., Kepalaite, A. (1996). Mokymasis ir asmenybès brendimas. Vilnius: Margi raštai, 233-236.

Butkienè G. (1995). Mokymosi psichologija. Vilnius: Vilniaus pedagoginio instituto leidykla.

Dereškevičius, P., Rimkevičienè, V., Targamadzè, V. (2000). Mokyklos nelankymo priežastys. Vilnius: Žuvèdra.

Edwards, J. (1994). Multilingualism. London: Routledge.

Gudonis, V., Rumšienè J. (2012). Mokinių mokymosi motyvų tyrimas. Profesinès studijos: teorija ir praktika, 10, 49- 59.

Juška A. (1997). Paaugliu teigiamo požiūrio ị mokymąsi ugdymas. Kaunas: Šviesa.

Kaffemanienè, I., Ivoškutė, J. (2005). Moksleivių, turinčių specialiųjų ugdymo(si) poreikių, mokyklinio nerimo poveikis mokymosi motyvacijai. Specialusis ugdymas: mokslo darbai, 2 (13), p. 5-67. 30.

Lehmann, I. (2009). Motyvacija: kaip tèvai galètu padèti savo vaikams. Vilnius: Gimtasis žodis.

Leonavičius, J. (1996). Stojimo ị aukštają mokyklą veiksnių ir motyvų kitimas. Filosofija, sociologija, 3,18-25. 
Lipinskaite, (2002). Edukacine studenta igalinanti studijuoti aplinka: daktaro disertacija, Kauno technologijos universitetas.

Paliukaite, N. (2005). Būsimųų mokytojų mokymosi motyvacijos psichologiniai parametrai. Acta paedagogica Vilnensia, 14, 59-66.

Paliukaitè, N. (2007). Būsimųų mokytojų mokymosi motyvų, savivertès bei savijautos mokantis sąsajos. Pedagogika, 85, 53-60.

Radzevičiūtè (2003). Stojimo ị Vilniaus universitetą motyvai. Pedagogika, 65, 232-240.

Ruggiero, V. R. (1998). Changing Attitudes: A Strategy for Motivating Students to Learn. Needham Heights: Allyn and Bacon.

Rupšienè, L. (2004). Mokyklinès klasės İtaka mokinių mokymosi motyvacijai. Pradine mokykla: Ugdymo turinys ir socialine integracija: žurnalo „Tiltai“ priedas, 22,116127.

Rupšienè, L. (1999). Hiperaktyviu vaiku ugdymo mokykloje problemos. Vaiku psichologinis konsultavimas. Vilnius: Presvika.

Rupšienė, L. (2000). Nenoras mokytis - socialinis pedagoginis reiškinys. Monografija. Klaipeda: Klaipèdos universiteto leidykla.

Salienè, V. (2011). Mokymosi motyvaciją formuojantys veiksniai. Žmogus ir žodis, 1(13), $100-104$.

Spurga, V. (2000). Saviugdos motyvu formavimas. Pedagogika, 40, 56-65.

Šiaučiukienè, L., Visockienè, O., Talijūnienè, P. (2006). Šiuolaikinis didaktikos pagrindai. Kaunas: Technologija.

Teresevičienė, M., Gedvilienė, D., Zuzavičiūtè ,V. (2006). Andragogika. Kaunas: VDU.

Vygotsky, L. S. (1999). Min din Society: the Development of Higher Psychological Processes. Cambridge: Harvard University Press.

Гудонис, В. (1979). Мотивы учения у работающей молодежи и взросльх с нарушением зрения. Диссертация на соискание ученой степени канд. пед. наук: Ленинград.

Гудонис, В. (1979a). К вопросу о мотивах учения взрослых в учебно производственных предприятиях общества слепых. Дефектология, 2, 25-31.

Гудонис, В. (1984). Мотивы учения лии с нарушениями зрения и некоторые пути их воспитания. Монография: Вилънюс.

Гудонис, В. (1989). Мотиващия общественной деятельности лии с нарушениями зрения. В кн. Тифлологические исследования. Вильнюс, 96-107.

Подласый, И. П. (1999). Педагогика. Москва: Владос.

Солнцева, Л. И. (1977). Роль мотивов в роднировании в формировании активности слепых дошкольников. В кн. Изучение личности аномалъного ребенка: Москва.

Стернина, Э. М. (1965.) Формирование мотивов общественной деятельности у слабовидящих подростков. XVIII Гериеновские чтения. Педагогические науки. Ленинград: ЛГПИ им. А. И. Герцена. 